PACS: 95.30.Sf, 98.62.Sb

UDC: $530.122,514.823,523.163$

\title{
The number of images of a point source in an N-point gravitational lens
}

\author{
K.A. Kotvytska ${ }^{1}$, E.S Bronza ${ }^{2}$, L.A. Kotvytska ${ }^{3}$
}

\author{
1 Department of Physics, Ukrainian State University of Railway Transport, Feuerbach sq 7, 61050 Kharkiv, Ukraine \\ 2 Faculty of Computer Science, Kharkiv National University of Radio Electronics, Nauky Ave. 14, 61166 Kharkiv, Ukraine, \\ 3 Department of Low-Temperature Physics, V.N. Karazin Kharkiv National University, Svobody sq. 4, 61022 Kharkiv, Ukraine \\ eugene.bronza@gmail.com, lilya18kotv@gmail.com
}

ORCID: 0000-0001-6629-5102

DOI: $10.26565 / 2222-5617-2019-30-07$

An important problem of the theory of gravitational lensing is the problem of studying images of a given source in a given lens. A special case of this problem is the problem of the number of images of a point source in a planar N-point gravitational lens. On this issue, several papers have been published. Most of the works are devoted to the upper bound on the number of images. However, there is no work on the lower bound on the number of images. The present work is devoted to this question.

The article calculates what the minimum number of images of a point source in an N-point gravitational lens is equal to. Proven the theorem about infimum of a number of point source images in the N-point gravitational lens. Is proved that this limit is being reached. In particular, it is established that a point source has a minimum number of images in the lens if all point masses are equal and located on the abscissa axis. Besides, the source is also on the abscissa axis. Regular and non-regular cases are considered. Using the theorem that was proved in the paper and the previously known results, a classification theorem about the number of images of a point source in an N-point gravitational lens is formulated.

The theorem proved in this paper is illustrated by an example of point source images in a binary lens. The point masses in this lens are the same and are located on the abscissa axis symmetrically with regard to the origin of the coordinates. The minimum number of point source images, in this case, is three, and the maximum is five. A point source has a minimum number of images if it is located on the abscissa axis.

The paper used methods of mathematical analysis, theory of functions of real variables and algebraic geometry.

Keywords: gravitational lens, point source, number of images, caustic.

\section{Кількість зображень точкового джерела в N-точковій гравітаційній лінзі}

\author{
К.А. Котвицька ${ }^{1}$, С.С. Бронза 2 , Л.А. Котвицька ${ }^{3}$ \\ 1 Украӥнський державний університет залізничного транспорту, пл. Фейєрбаха, 7, Харків 61050, Украӥна \\ 2 Харківський наиіональний університет радіоелектроніки, проспект Науки 14, 61166 Харків, Україна \\ 3 Харківський національний університет імені В.Н. Каразіна, м. Свободи 4, 61022, Харків, Україна
}

Важливим завданням теорії гравітаційного лінзування є завдання вивчення зображень заданого джерела в заданій лінзі. Окремим випадком цього завдання є завдання про кількість зображень точкового джерела в плоскій $\mathrm{N}$ - точкової гравітаційної лінзи. 3 цього питання опубліковано кілька робіт. Більшість робіт присвячено верхній межі числа зображень. Однак, серед них, відсутні роботи про нижнію межу числа зображень. Цьому питанню присвячена ця робота.

У роботі встановлено, чому дорівнює мінімальне число зображень точкового джерела в $\mathrm{N}$ - точковій гравітаційній лінзі. Доведено теорему про нижню границю кількості точкових зображень, точкового джерела, в N-точковій гравітаційній лінзі. Доведено, що ця границя досягається. Зокрема встановлено, що точкове джерело має мінімальне число зображень в лінзі, якщо все точкові маси рівні і знаходяться на осі абсцис. I, крім того, джерело також знаходиться на осі абсцис. Розглянуто регулярний і не регулярний випадки. Використовуючи доведену в роботі теорему, і раніше відомі результати, сформульована класифікаційна теорема, про кількість зображень точкового джерела в $\mathrm{N}$ - точковій гравітаційній лінзі.

Доведену в роботі теорему ілюструє приклад про зображення точкового джерела в бінарній лінзі. Точкові маси в цій лінзі однакові і розташовані на осі абсцис симетрично відносно початку координат. Мінімальна кількість зображень точкового джерела, в цьому випадку, дорівнює трьом, а максимальна п'яти. Точкове джерело має мінімальне число зображень, якщо воно розташовано на осі абсцис.

У роботі використані методи математичного аналізу та алгебри геометрії.

Ключові слова: гравітаційна лінза, точкове джерело, число зображень, каустика.

\section{Количество изображений точечного источника в N-точечной} гравитационной линзе

К.А. Котвицкая ${ }^{1}$, Е.С. Бронза ${ }^{2}$, Л.А. Котвицкая ${ }^{3}$

(C) Kotvytska K.A., Bronza E.S, Kotvytska L.A., 2019 
1 Украинский государственный университет железнодорожного транспорта, Фейербаха пл., 7, г. Харьков 61050, Украина 2 Харьковский национальный университет радиоэлектроники, пр. Науки 14, 61166 Харьков, Украина

3 Харьковский национальный университет имени В.Н. Каразина, м. Свободы 4, 61022, Харьков, Украина

Важной задачей теории гравитационного линзирования является задача изучения изображений заданного источника в заданной линзе. Частным случаем этой задачи есть задача о числе изображений точечного источника в плоской $\mathrm{N}$ точечной гравитационной линзе. По этому вопросу опубликовано несколько работ. Большинство работ посвящены верхней границе числа изображений. Однако отсутствуют работы о нижней границе числа изображений. Этому вопросу посвящена настоящая работа.

В работе установлено, чему равно минимальное число изображений точечного источника в $\mathrm{N}$ - точечной гравитационной линзе. Доказана теорема о нижней границе числа точечных изображений, точечного источника, в Nточечной гравитационной линзе. Доказано, что эта граница достигается. В частности установлено, что точечный источник имеет минимальное число изображений в линзе, если все точечные массы равны и находятся на оси абсцисс . И, кроме того, источник также находится на оси абсцисс. Рассмотрен регулярный и не регулярный случаи. Используя доказанную в работе теорему, и ранее известные результаты, сформулирована классификационная теорема, о числе изображений точечного источника в $\mathrm{N}$ - точечной гравитационной линзе.

Доказанную в работе теорему иллюстрирует пример об изображениях точечного источника в бинарной линзе. Точечные массы в этой линзе одинаковы и расположены на оси абсцисс симметрично относительно начала координат. Минимальное число изображений точечного источника, в этом случае, равно трем, а максимальное пяти. Точечный источник имеет минимальное число изображений, если он расположен на оси абсцисс.

В работе использованы методы математического анализа и алгебраической геометрии.

Ключевые слова: гравитационная линза, точечный источник, количество изображений, каустика.

\section{Statement of the problem}

The equation of a flat, $\mathrm{N}$ - point gravitational lens in vector form is $[1,2]$ :

$$
\vec{y}=\vec{x}-\sum_{n} m_{n} \frac{\vec{x}-\vec{l}_{n}}{\left|\vec{x}-\vec{l}_{n}\right|^{2}}, \quad \sum_{n=1}^{N} m_{n}=1,
$$

where $m_{n}$, are the dimensionless point masses that enter the lens, and $\vec{l}_{n}$ are their normalized radius vectors. Vector equation (1) defines a unique mapping

$$
L:\left(R_{X}^{2} \backslash \Lambda\right) \rightarrow R_{Y}^{2}
$$

from the vector space $R_{X}^{2}$ to the vector space $R_{Y}^{2}$.

From the algebraic point of view, the problem of the number of images of a point source in an $\mathrm{N}$-point gravitational lens is the problem of the number of solutions of equation (1).

For further discussion, we consider equation (1) in coordinate form:

$$
\left\{\begin{array}{l}
y_{1}=x_{1}-\sum_{n=1}^{N} m_{n} \frac{x_{1}-a_{n}}{\left(x_{1}-a_{n}\right)^{2}+\left(x_{2}-b_{n}\right)^{2}} \\
y_{2}=x_{2}-\sum_{n=1}^{N} m_{n} \frac{x_{2}-a_{n}}{\left(x_{1}-a_{n}\right)^{2}+\left(x_{2}-b_{n}\right)^{2}}
\end{array},\right.
$$

where $\left(a_{n}, b_{n}\right)$ is the coordinate of the point $A_{n}$ is the end of the radius vector $\vec{l}_{n}$. The set of solutions of system (2.3) can be studied by methods of algebraic geometry; see, for example, $[3,4]$.

\section{Basic research results on the number of images of a point source in a Schwarzschild lens and in other $\mathrm{N}$ - point gravitational lenses.}

The set of solutions to the system of equations (2) can have the dimension $\operatorname{dim} V^{0}\left(F_{1}, F_{2}\right)=0$ or $\operatorname{dim} V^{1}\left(F_{1}, F_{2}\right)=1$. There are a number of theorems that allow us to determine whether the set $V^{1}\left(F_{1}, F_{2}\right)$ is empty.

Theorem 1. The only image of dimension 1 (a point source) is an infinitely thin Einstein ring. This image appears only in the Schwarzschild lens when the source, lens and observer are on the same line, see [4].

If the source, lens and observer are not on the same line, then the point source in the Schwarzschild lens has an image consisting of two points, see [2].

For the N-point gravitational lens there are theorems.

Theorem 2. The number of point images of a point source in an N-point gravitational lens is bounded above:

$$
\operatorname{card}\left(V^{0}\left(f_{1}, f_{2}\right)\right) \leq N^{2}+1 .
$$

Estimate (4) is achievable, see [5,6].

Theorem 3. In a general situation, the number of point images in an $\mathrm{N}$-point gravitational lens has parity opposite to the parity of $\mathrm{N}$, see [5].

Inequality (4) limits the number of point images of an exact source from above.

The number of point images of a point source, in a general situation, cannot be less than $N+1$.

\section{The main theorem}

The following theorem holds.

Theorem 4. The number of point images, a point source, in an N-point gravitational lens is bounded below: 


$$
N+1 \leq \operatorname{card}\left(V^{0}\left(f_{1}, f_{2}\right)\right)
$$

Estimate (5) is achievable.

Proof. Let in the N-point gravitational lens all point masses are equal and are on the abscissa axis, which is. Suppose, in addition, the source is also located on the abscissa axis.

The following system of equations is valid:

$$
\left\{\begin{array}{l}
y_{1}=x_{1}-\frac{1}{N} \sum_{i=1}^{N} \frac{x_{1}-a_{i}}{\left(x_{1}-a_{i}\right)^{2}+x_{2}^{2}} \\
0=x_{2}-\frac{1}{N} \sum_{i=1}^{N} \frac{x_{2}}{\left(x_{1}-a_{i}\right)^{2}+x_{2}^{2}}
\end{array} .\right.
$$

The second equation of system (6) splits into two equations, indeed:

$$
\left\{\begin{array}{c}
y_{1}=x_{1}-\frac{1}{N} \sum_{i=1}^{N} \frac{x_{1}-a_{i}}{\left(x_{1}-a_{i}\right)^{2}+x_{2}^{2}} \\
0=x_{2}\left(1-\frac{1}{N} \sum_{i=1}^{N} \frac{1}{\left(x_{1}-a_{i}\right)^{2}+x_{2}^{2}}\right)
\end{array} .\right.
$$

System (7) splits into two subsystems:

$$
\left\{\begin{array}{c}
y_{1}=x_{1}-\frac{1}{N} \sum_{i=1}^{N} \frac{x_{1}-a_{i}}{\left(x_{1}-a_{i}\right)^{2}+x_{2}^{2}}, \\
0=x_{2}
\end{array}\right.
$$

and

$$
\left\{\begin{array}{c}
y_{1}=x_{1}-\frac{1}{N} \sum_{i=1}^{N} \frac{x_{1}-a_{i}}{\left(x_{1}-a_{i}\right)^{2}+x_{2}^{2}} \\
0=1-\frac{1}{N} \sum_{i=1}^{N} \frac{1}{\left(x_{1}-a_{i}\right)^{2}+x_{2}^{2}}
\end{array} .\right.
$$

The set of solutions to system (6) is the union of solutions to system (8) and solutions to system (9).

From the system (9) follows the equation (all point masses are equal and are on the abscissa axis):

$$
y_{1}=x_{1}-\frac{1}{N} \sum_{i=1}^{N} \frac{1}{x_{1}-a_{i}}
$$

We denote the variable $x_{1}$ by $t$, i.e., $t=x_{1}$.

Equation (10) can be converted to the form:

$$
y_{1}=t-\frac{P^{\prime}(t)}{P(t)}
$$

where $P(t)=\prod_{i=1}^{N}\left(t-a_{i}\right)$ is a polynomial of degree $N$ with real multiple roots of $a_{i}$. The roots of the polynomial are not multiple
Without loss of generality, we have that the inequality holds for numbers:

$$
a_{1}<a_{2}<\ldots<a_{i}<a_{i+1}<\ldots<a_{N} .
$$

If this is not so, renumber the roots of the polynomial $P(t)$ in ascending order.

The polynomial $P^{\prime}(t)$ has $N-1$ roots. Each segment $\left(a_{i}, a_{i+1}\right)$ (Role's theorem) has at least one root of the polynom $P^{\prime}(t)$. The number of segments and the number of roots of the polynomial $P^{\prime}(t)$ are equal. From here, only one root belongs to each segment.In addition, all the roots of the $P^{\prime}(t)$ polynomial are real.

Let $c_{i}$ be the root of the polynomial $P^{\prime}(t)$ that belongs to the segment $\left(a_{i}, a_{i+1}\right)$. We have the inequality:

$$
a_{1}<c_{1}<a_{2}<c_{2}<\ldots<a_{i}<c_{i}<a_{i+1}<c_{i+1}<\ldots<c_{N-1}<a_{N} .
$$

Let the rational function $Q(t)=\frac{P^{\prime}(t)}{P(t)}$. The function has:

- breaks in points $a_{i}, i=1,2, \ldots, N$;

- vertical asymptotes with the equation $t=a_{i}, i=1,2, \ldots, N$;

- zeros at points $c_{i} \quad i=1,2, \ldots, N-1$;

- limits on the left $\lim _{t \rightarrow a_{i}-0} Q(t)=-\infty$ at points $a_{i} \quad i=1,2, \ldots, N$;

- limits to the right $\lim _{t \rightarrow a_{i}+0} Q(t)=\infty$ at points $a_{i} \quad i=1,2, \ldots, N$

- continuity intervals $\left(-\infty, a_{1}\right),\left(a_{1}, a_{2}\right), \ldots,\left(a_{i}, a_{i+1}\right)$, $\ldots,\left(a_{N}, \infty\right)$;

- intervals of monotonous decrease $\left(-\infty, a_{1}\right),\left(a_{1}, a_{2}\right)$, $\ldots,\left(a_{i}, a_{i+1}\right), \ldots,\left(a_{N}, \infty\right)$.

To calculate the number of real roots of equation (11), we apply geometric reasoning.

The roots of equation (11) will be the abscissas of the intersection points of the graphs of two functions:

$$
q=\frac{P^{\prime}(t)}{P(t)} \text { and } q=t-y_{1}
$$

The coordinates of the intersection points of the graphs of these functions are set of solutions to the system of equations: 


$$
\left\{\begin{array}{l}
\frac{P^{\prime}(t)}{P(t)}=q \\
t-y_{1}=q
\end{array} .\right.
$$

Let us prove that the system of equations (12) has exactly $N+1$ solutions. Consider the plane $R^{2}$ with the coordinate system $t O q$. In this plane, the graph of the PP function is a straight line. This line crosses the graph of the rational function of $q=\frac{P^{\prime}(t)}{P(t)}$, just $N+1$ times. On each continuity interval, the function graphs intersect exactly once.

Therefore, equations (11) and (10) and system (9) have just $N+1$ solutions.

Obviously, system (6) has at least $N+1$ solutions.

The number of solutions to system (6) is exactly $N+1$ if system (9) does not have real solutions.

The case when system (9) does not have real solutions is obviously realized.

Really, from the second equation of system (9) it follows:

$$
\begin{aligned}
& \frac{1}{N} \sum_{i=1}^{N} \frac{1}{\left(x_{1}-a_{i}\right)^{2}+x_{2}^{2}}=1 \Rightarrow \frac{1}{\frac{1}{N} \sum_{i=1}^{N} \frac{1}{\left(x_{1}-a_{i}\right)^{2}+x_{2}^{2}}}=1 \Rightarrow \\
& \Rightarrow H\left(\left|x-a_{1}\right|^{2},\left|x-a_{2}\right|^{2}, \ldots,\left|x-a_{N}\right|^{2},\right)=1
\end{aligned}
$$

where $H\left(\left|x-a_{1}\right|^{2},\left|x-a_{2}\right|^{2}, \ldots,\left|x-a_{N}\right|^{2},\right)$ is the harmonic mean of the squares of the distances from the origin to the point masses.

From equation (13) it follows that the harmonic mean is equal to unity.

Note that the harmonic mean is the "mean" in the sense that:

$$
\begin{gathered}
\operatorname{mix}\left(c_{1}, c_{2}, \ldots, c_{N}\right) \leq H\left(c_{1}, c_{2}, \ldots, c_{N}\right) \leq \\
\leq \operatorname{man}\left(c_{1}, c_{2}, \ldots, c_{N}\right)
\end{gathered} .
$$

It follows from equation (14) that equation (13) and system (9) obviously have no solutions if the distances between any two point masses in the lens are greater than two.

Thus, the lower limit of the number of images is achieved. The theorem is proved.

\section{The Classification Theorem}

There is the classification (systematizing) theorem.

Theorem 5. The number of point images of a point source in an $\mathrm{N}$-point gravitational lens:

- can take all values from $N+1$ to $N^{2}+1$;
- in a general situation, the number of images is even if $N$ is odd, and odd if $N$ is even;

- number of images has the same parity as the number $N$ if the source belongs to a non-singular point in the caustic;

- in a general situation, the number of images changes by two if the source path crosses the caustic.

Comment. Using computer simulation methods, it was proved that for and the smallest number of images is 3 and 4 , respectively.

\section{The Example}

Let a binary lens have masses $m_{1}=\frac{1}{2}$ and $m_{2}=\frac{1}{2}$, which are located at points $A_{1}(-b, 0)$ and $A_{2}(b, 0)$.

In this case, the system of lens equations has the form:

$$
\left\{\begin{array}{l}
y_{1}=x_{1}-\frac{1}{2}\left(\frac{x_{1}+b}{\left(x_{1}+b\right)^{2}+x_{2}^{2}}+\frac{x_{1}-b}{\left(x_{1}-b\right)^{2}+x_{2}^{2}}\right) \\
y_{2}=x_{2}-\frac{1}{2}\left(\frac{x_{2}}{\left(x_{1}+b\right)^{2}+x_{2}^{2}}+\frac{x_{2}}{\left(x_{1}-b\right)^{2}+x_{2}^{2}}\right)
\end{array}\right.
$$

Consider a special case. Let the source be a point and be on the ordinate axis.

In this case (16) splits into two subsystems.

$$
\left\{\begin{array}{l}
y_{1}=x_{1}-\frac{1}{2}\left(\frac{x_{1}+b}{\left(x_{1}+b\right)^{2}+x_{2}^{2}}+\frac{x_{1}-b}{\left(x_{1}-b\right)^{2}+x_{2}^{2}}\right) \\
0=x_{2}\left(1-\frac{1}{2}\left(\frac{1}{\left(x_{1}+b\right)^{2}+x_{2}^{2}}+\frac{1}{\left(x_{1}-b\right)^{2}+x_{2}^{2}}\right)\right)
\end{array} .\right.
$$

The first of the subsystems has no solutions if $b>1$. For the second subsystem we have:

$$
\begin{gathered}
\left\{\begin{array}{r}
y_{1}=x_{1}-\frac{1}{2}\left(\frac{x_{1}+b}{\left(x_{1}+b\right)^{2}+x_{2}^{2}}+\frac{x_{1}-b}{\left(x_{1}-b\right)^{2}+x_{2}^{2}}\right) \Rightarrow \\
0=x_{2}
\end{array}\right. \\
\Rightarrow\left\{\begin{array}{c}
y_{1}=x_{1}-\frac{1}{2}\left(\frac{1}{x_{1}+b}+\frac{1}{x_{1}-b}\right) \Rightarrow \\
0=x_{2}
\end{array}\right. \\
\Rightarrow\left\{\begin{array}{c}
y_{1}=x_{1}-\frac{x_{1}}{x_{1}^{2}-b^{2}} \Rightarrow\left\{\begin{array}{c}
y_{1}=\frac{x_{1}^{3}-\left(b^{2}+1\right) x_{1}}{x_{1}^{2}-b^{2}} \\
0=x_{2}
\end{array}\right. \\
0=x_{2}
\end{array}\right. \\
x_{1}^{3}-y_{1} x_{1}^{2}-\left(b^{2}+1\right) x_{1}+b^{2} y_{1}=0
\end{gathered}
$$


The Equation (18) for any real values of $y_{1}$ has three real roots, and all the roots are different. Really:

$$
x_{1}^{3}-y_{1} x_{1}^{2}-\left(b^{2}+1\right) x_{1}+b^{2} y_{1}=0 \Rightarrow y_{1}=\frac{x_{1}^{3}-\left(b^{2}+1\right) x_{1}}{x_{1}^{2}-b^{2}} \text {. }
$$

Function graph

$$
y_{1}=\frac{x_{1}^{3}-\left(b^{2}+1\right) x_{1}}{x_{1}^{2}-b^{2}}
$$

crosses the abscissa axis three times and has two vertical asymptotes, see Fig. 1.

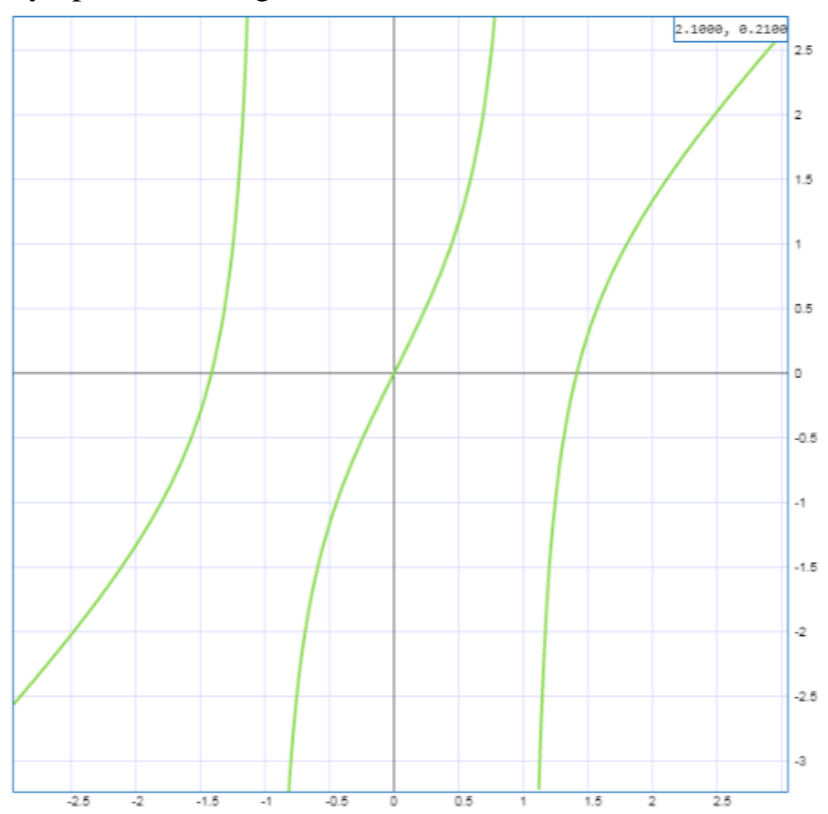

Fig. 1.

It follows from the example that for any value of the ordinate $y_{1}$ there are three values of the abscissa of $x_{1}$, and they are different. Therefore, the minimum number of images for a binary lens is 3 .

\section{References}

1. A.F. Zakharov. Gravitacionnye linzy I mikrolinzy, Janus-K, M. (1997). $328 \mathrm{c}$.

2. P. Schneider, J. Ehlers, E.E. Falco. Gravitational lenses, Springer-Verlag, Berlin Heidelberg (1999), p. 560.

3. S.D. Bronza, A.T. Kotvytskiy. Bulletin of V.N. Karazin Kharkiv National University (Physics), 26, 1120, 6 (2017).

4. A.T. Kotvytskiy, S.D. Bronza, K.Ju. Nerushenko, V.V. Shablenko. Zbirnyk naukovyh prac VI Migregionalnoj naukovo-praktychnoj konferencii «Astronomija I sogodenna» Vinnyca (2017), s.198.
5. A.T. Kotvytskiy, S.D. Bronza, S.R. Vovk. Bulletin of V.N. Karazin Kharkiv Karazin National University (Physics), 24, 55 (2016). (arXiv:1809.05392)

6. O.A. Osmaev, K.V. Matvienko. Tezy 80 CNTK UkrDUZT, Kharkiv (2018), s. 216 